[in Ukrainian].

Strazhnikova, I. (2013). Dzherelna baza istoryko-pedahohichnykh doslidzhen Zakhidnoho rehionu Ukrainy [Source base of historical-pedagogical researches of the western region of Ukraine]. In I.M. Shorobura (Ed.). Pedahohichnyi dyskurs: zbirnyk naukovykh prats, 15, 687-691. Khmelnytskui: KhHPA [in Ukrainian].

УДК 378.014.61(485)(043.5)

DOI: https://doi.org/10.35387/od.1(19).2021.170-179

Kotun Kyryl - Candidate of Pedagocial Sciences (PhD in Pedagogy), Senior Researcher at Department of Pedagogical Education and Adult Education, Doctoral Student at Ivan Ziaziun Institute of Pedagogical Education and Adult Education of NAES of Ukraine
Котун Кирил Васильович кандидат педагогічних наук, старший науковий співробітник відділу зарубіжних систем педагогічної освіти $і$ освіти дорослих, докторант Інституту педагогічної освіти $i$ освіти дорослих імені Івана Зязюна НАПН України

ORCID iD: http://orcid.org/0000-0002-3661-6689

E-mail:smartk@ukr.net

\title{
FEATHERS OF LIFELONG TEACHER EDUCATION IN SWEDEN
}

Abstract. Nowadays, lifelong teacher education is an important lifelong learning component is conditioned not only by the dynamics of social, scientific and technological progress, changes in the scope and nature of work, increasing leisure time, and opportunities for its rational use but also by the social role of both society and personality. Quality education is considered by the world community as a tool of socio-economic growth and cultural development. Modern pedagogical reality is characterized by a tendency to find ways to improve higher education and reform. Sweden is one of the most developed socio-economic countries in the world. And the study of the experience of this particular country should help improve the training of native teachers. Teacher education in the Scandinavian countries has its own special socio-cultural significance and contains several dimensions that characterize the individual: education as an individual condition, education as an individual opportunity; education as an individual process; education as the highest value of mankind. It should be noted that the system of modern pedagogical education in Sweden is quite flexible and meets the needs of society in the number and qualifications of teachers. Also teacher has the opportunity in a lifelong pedagogical profile development. In order to ensure the continuous professional growth of teachers in Sweden, a system for improving their qualifications has been developed, regulated at various levels. That is why in conditions of integration processes, modernization of pedagogical education of Ukraine in accordance with the provisions of the Bologna 
Declaration, the system of professional education of Ukraine faced new tasks, the solution of which is due to increasing the role of personality and teacher professionalism as specialists and citizens in a market economy.

Key words: teacher training; professional development; feathers, lifelong; Sweden.

Котун Кирил Васильович ОСОБЛИВОСТІ НЕПЕРЕРВНОЇ ПЕДАГОГІЧНОЇ ОСВІТИ У ШВЕЦІЇ

Анотація. Автором обгрунтовано, що сучасна неперервна професійна освіта вчителів $\epsilon$ важливою складовою навчання протягом усього життя, зумовленою не тільки динамікою соціального, науковотехнічного прогресу, змінами обсягу та особливостей праці, збільшенням дозвілля та можливостей його раціонального використання, а й соціальною роллю як суспільства, так й особистості. Якісна освіта розглядається світовим співтовариством як інструмент соціально-економічного зростання і культурного розвитку. Виявлено, що сучасна педагогічна реальність характеризується тенденцією пошуку шляхів удосконалення вищої освіти та ї̈ реформування. Швеція є однією з найбільш розвинених соціально-економічних країн світу. I вивчення досвіду саме цієї країни повинно допомогти вдосконалити підготовку та розвиток українських педагогів. Обгрунтовано, що педагогічна освіта Скандинавських країн має особливе соціокультурне значення та уособлює кілька вимірів, що характеризують індивіда: освіта як індивідуальний стан, освіта як індивідуальна можливість; освіта як індивідуальний процес; освіта як найвища цінність людства. Доведено, що система сучасної педагогічної освіти Швеції досить гнучка й задовольняє потреби суспільства в кількості і якості вчителів, при цьому у педагога $є$ можливість коригування свого педагогічного профрілю протягом усього життя. В умовах інтеграційних процесів, модернізації педагогічної освіти України відповідно до положень Болонської декларації постали нові завдання, шляхи розв'язання яких зумовлені підвищенням ролі особистості і профресіоналізму вчителя як фрахівця $і$ громадянина для поліпшення соціального економічного, культурного життя суспільства в умовах ринкової економіки.

Ключові слова: педагогічна підготовка; профресійний розвиток; особливості; неперервність; Швеція.

Problem statement and its rationale. Teacher training in Sweden is part of the university structure and is found in more than twenty educational institutions. In 2001 a reform was instigated whereby the curricula and organization of teacher training was radically changed. In the parliamentary committee delineating this reform the 'new' multicultural Sweden and the impact of globalization was mentioned as important factors underlining the need for a new teacher training. The reform also gave increased opportunities for teacher training colleges to create their own profiles in order to attract students on an 
increasingly competitive educational market (Rabo, 2007).

Sweden has been profoundly transformed through the impact of immigration. One in every ten resident has been born outside Sweden and one in every five has at least one parent who has born abroad. An increasing number of migrants maintain, or develop, strong transnational links to their country of origin. Some migrants are developing diasporic communities. Also an increasing number of 'ethnic' Swedes establishing more global links through studies, work and travel abroad. The Swedish parliament and all official Sweden institutions laud these links, and Sweden is officially declared to be a multicultural society where cultural diversity is said to enrich the country (and make it more competitive on the global market).

But 'cultural diversity' is not evenly spread in Sweden. While large parts of rural and small-city Sweden continue to be mono-culturally 'Swedish', it is the suburbs of the larger cities which have come to represent cultural diversity. And despite the official lauding of multiculturalism in Sweden, schools in such communities are faced with a number of very concrete problems (Rabo, 2007).

In 1996 a Swedish state-commissioned report officially declared the country to be a multicultural society. According to this report, the shift from a mono-cultural and homogenous to a diverse and multicultural society was caused by increased international movement of people and ideas, and mainly by the significant number of immigrants, or citizens with at least one parent born in another country. The aim of the report was to put forward new policies towards immigrants. Although some members of Parliament had reservations about its conclusions, the report - Sweden, the Future and Diversity - was generally regarded as heralding the new political consensus on immigrants in Sweden.

Teacher training, and hence also schools, are today asked to enhance both 'similarities' and 'differences'. Teaching in all schools must, according to the law, rest on the so-called 'basic values' on which Swedish society rests. Such ideals as the equal worth of all human beings, equality between women and men, the freedom and integrity of each individual, and solidarity with people in need stress the similarity between human beings, and the right to be treated in a similar fashion, regardless of sex, age, or ethnic, religious or social background (Rabo, 2007). At the same time the task of the school is to encourage all pupils to discover their own uniqueness as individuals and thereby actively participate in social life by giving of their best in responsible freedom' (Lpo 94:5).vi Teacher-training institutions are thus faced with a dual task. They must train the future teachers simultaneously to respect and enhance similarities and differences.

The purpose of the article is to show feathers of lifelong teacher education, training and development in Sweden.

Presentation of the basic material. Likely the first attempt to raise professional standards for teachers arose in 1803. The state required teachers to pass a university examination to demonstrate proficiency in academic studies in order to teach. The first teacher-training center was instituted in 1842, 
coinciding with a perceived need for professionals that would be needed in the classroom with the passage of mandatory school attendance by law. Localities known as parishes were required to engage the services of one or more trained individuals as teachers. Before 1842, most of Sweden's teachers were male and were often priests (Sweden - Teaching Profession, 2020).

Sweeping changes with regard to the qualifications of teachers took place in 1977. Before that year, the educational institutions for the training of primary school teachers were not a part of the government-run system of higher education. Qualifications for secondary school teachers were more stringent than those imposed on the primary teachers. The secondary teachers were required to obtain a full university degree, almost always majoring in two subjects that often became the subjects they taught their students, plus one additional year while taking required training in education.

In 1977, after the reforms, both primary and secondary teachers took their work in a recognized institution or education institute belonging to Sweden's system of higher education. In addition, potential teachers in specialties such as art, music, and physical education (as they had before 1977) went to special places offering training to those seeking an expertise in order to teach (Sweden - Teaching Profession, 2020).

Until sweeping improvements in teacher education and certification were introduced in 1988, there were large-scale differences between the amount and quality of training of teachers in Sweden at the three main levels of compulsory schools (Sweden - Teaching Profession, 2020).

- The first level was the lågstadielärare, or lower-level teachers, requiring 100 credit points for a certificate in primary education, grades one through three.

- The next level was the mellanstadieläärare, or intermediate grade teachers, requiring 120 credit points for a Bachelor of Education in Primary Education, grades four through six.

- The third level was äämneslärare, or teachers for the upper level, also known as lower secondary school. The level required between 160 and 180 credit points. The degree was Master of Arts or Master of Science with a notation as to subject specialty and specialties.

- Outside these levels, there were teaching positions that came under the categories of the arts and practical subjects. These had additional requirements for credit points set by the state.

More changes in the requirements for teachers to successfully gain authorization to teach in Sweden were passed by the state in 1988. These reforms particularly addressed teachers in compulsory schools (Sweden Teaching Profession, 2020). Among the requirements, teachers needed to:

- Take and pass one year of education courses to satisfy a 40-point course requirement. Some students take the requirement in a single year or sometimes even longer than one year should unusual circumstances dictate. Some take the required coursework a few points each year while attending an institute of higher learning until the 40-point total is reached. In Sweden, one week of full-time studies earns one poäng or credit point, and 40 points is one 
year's required work in pedagogy and practice teaching for teacher certification.

- These courses, referred to as praktisk-pedagogisk utbildning, include teacher training, practice teaching, and pedagogy.

Behind all this training is the reasoning that those who seek a teaching career in Sweden must be prepared to satisfy rigorous requirement for teacher certification. Teachers form a sort of professional guild in this nation, and those whose university degrees were earned with a teaching career specifically in mind have traditionally been chosen by the government for teaching positions.

However, with decentralization going into effect in 2001, and earlier reforms in place as early as 1992, the headmasters or other administrative heads of local schools have been the taking control of the teaching profession from government. Thus, regulations need not be so restrictive as to, for example, keep potential teachers out of the classroom who have made this professional decision later in life after already having one successful career. Potential employers can evaluate a teaching candidate's curriculum and determine if this person's experiences and academic preparation make him a good candidate for the position or not.

In 2000, the agency in charge of evaluating the credentials of nonSwedish applicants and applicants for permanent teacher certification is the National Agency for Higher Education (NAHE). Essentially, the NAHE examines the qualifications and Swedish language competency of those who apply for certification, determining whether the candidate roughly measures up to those teachers who obtain teacher certification through standard means of a diploma from an accredited institution offering training for teachers (Sweden - Teaching Profession, 2020).

Numerous important teacher education reforms were implemented nationwide on July 1, 2001. These were part of a government bill passed by the Swedish Riksdag (parliament) in October, 2000. Of utmost importance for reducing bureaucracy, the practice of awarding eight separate teaching degrees was ended, and henceforth only one degree is to be awarded with two minor exceptions. The separate-degree exceptions are these two only: the Diploma of Education for the Folk High School and the Diploma of Education in Aviation.Although there is one diploma, there are some important differences in the credit points that teachers must take. Preschool, recreation, and compulsory school teachers of lower grades must take 140 credit points, the equivalent of 3.5 years of study. Music teachers take 160 hours. Compulsory school teachers of the higher grades must take 180 credit points (Sweden - Teaching Profession, 2020).

Those who successfully complete Sweden's teacher education are awarded a diploma specifying specialization and status of qualification. The reforms reflected the desire of state authorities to award a diploma that required all candidates to demonstrate mastery of certain knowledge area in common, including the field of teacher education. To that end, students in common will take a maximum of sixty such credit hours, representing the equivalent of 1.5 years' coursework. The remaining coursework reflects the specialization and/or special study areas, including the requirement that students satisfy either a 
thesis or special project in order to graduate with a teaching credential.

Teachers already practicing can have access to the new teacher requirements through coursework available through traditional academic studies or through distance education. Rather than lock students into studies for life, the program allows students to qualify for new areas of specialization after taking the requisite additional course-work. The proposed requirements will allow for some individual variances in teacher preparation at the various institutions of study.

National Priorities, Cultures and Contexts. The education system and wider society and culture are focused on a widely-shared set of fundamental values. Educators aim to foster knowledge and value development, prepare students to live and work in society and develop students in creative, active, responsible and competent individuals and citizens. There is increasing investment in the education of $6-10 \mathrm{yr}$ olds. Swedish society has also embraced the value of lifelong learning. The Swedish adult population shows an aboveaverage proficiency in literacy, numeracy and problem solving in technologyrich environments, compared with other OECD countries (Teacher Identities and Professionalism Research, 2019).

PISA scores declined from 2000 to 2012 from around average to significantly below average. No other country taking part in PISA has seen a steeper fall. PISA 2016 results reversed the negative trend to bring Sweden in line with international averages. The government continues a programme of reform with 3 main priorities:

- Improving the attractiveness of the teaching profession (see right).

- Early intervention to address low attainment, (e.g) through the Reading/writing and arithmetic guarantee.

- Improving Equity /Equality between students where results show a widening attainment gap.

A Schools' commission of teachers, researchers and representatives from unions and organizational bodies was put together to produce a thorough overview and make proposals for a systemic approach to system improvement. This was informed by a "national gathering of teachers".

Another challenge presently shaping the system is that Sweden his becoming a more culturally diverse country. In 2013, $15 \%$ of the Swedish population was born abroad, putting Sweden among the OECD countries with the largest foreign-born population. Integration of immigrant families and children is therefore of key importance to Swedish society. Fast Track initiatives (2016) are in place to help for both pupils integrate into schools and to enable qualified foreign teachers to more quickly enter the profession with shortened teacher training (Teacher Identities and Professionalism Research, 2019).

Teacher Status and Autonomy. Teachers are required to work within the confines of the curriculum for compulsory schooling, which underwent reform in 2011. Local planning seeks to give practical expression to the goals set out in the Education Act, the curriculum and syllabi. Within Sweden's decentralised steering of the school system, the choice of tools and methods used to achieve this are left to school organisers to determine. 

society.

Swedish teachers do not see their profession as highly valued in

Individual teacher salaries are negotiated annually between principals and teachers. This has led to starting salaries slightly above the OECD average, but salaries at the top of the scale are far below average. The Teacher salary boost initiative (Lärarlönelyftet) allows principles to request up to 3000 SEK per month per teacher. In 2016/17 60,000 teachers are expected to benefit from pay increases.

Almost 1 in 5 (18\%) lower secondary teachers regret becoming a teacher, and only $53 \%$ would still choose to work as a teacher if they could decide again (Teacher Identities and Professionalism Research, 2019).

Training, employment and retention. There is currently an acute shortage of teachers and current projections point towards significant challenges in the mismatch between the supply and demand of new teachers, owing to low numbers of applicants to initial teacher education programmes, and the large anticipated number of teachers retiring or considering a career change. In 2015, against this backdrop, the OECD recommended that Sweden should improve the attractiveness of the teaching and school leadership profession.

Strategies for this include:

- Raising teacher salaries (Lärarlönelyftet).

- Developing professional standards to underpin appraisals and career structure.

- More selective entry into teacher education programmes.

- Adequately resourced CPDL for educators.

According to the OECD (2015), conditions in the Swedish system are not conducive to nurturing excellence in the teaching profession. Teaching is considered a low status and relatively unattractive profession. This is partly due to the heavy workload, relatively low salaries, limited opportunities for appraisal and feedback, and unclear relationships between principals and employers. In spite of this, teachers' sense of self-efficacy and job satisfaction is high. $85 \%$ report overall satisfaction with their jobs. $96 \%$ report being satisfied with their performance in their current school (Teacher Identities and Professionalism Research, 2019).

The quality of teachers is variable throughout Sweden. In the past, there have been reports of many teachers teaching subjects in which they are not qualified, and in 2012, 76.5\% of teachers held a university-level degree, leaving almost a quarter without the required qualification. In recent years (2011 onwards), reforms have been initiated to ensure a high quality workforce, and as of 2015, there are 4 university-level initial teacher education programmes, provided by 28 universities. Also, funding has been put in place to increase the support staff workforce to 20,000 (2017).

Professional development and Learning. A lack of career paths has for many years hindered the professional development of Swedish teachers. In recent years, however, two statuses were added to the career structure for teachers: First Teachers hold additional responsibilities and a higher salary. 
Senior Subject Teacher require a licentiate degree or above and must demonstrate at least 4 years of high quality teaching.

Responsibility for teacher CPDL is divided between the government and municipalities. Though not a legal requirement, Swedish teachers are currently entitled to 104 hours per year for CPDL during working hours. The NAE must ensure that in-service training courses are available in all parts of the country, while school organisers must ensure all staff are adequately trained. Other providers include educational broadcasters, teachers' unions, other state authorities and independent education companies (Teacher Identities and Professionalism Research, 2019).

Effective induction and mentoring programmes can help new teachers deal with the challenges during their first months of employment. However, participation in such programmes is low.

- In 2013, Swedish lower secondary teachers reported a lack of support mechanisms for new teachers.

- Newer teachers demonstrated much lower confidence in their abilities.

- Almost one third of lower secondary teachers receive no performance feedback at all; those who do typically receive it from the school principal, who they report as being poorly equipped for the task.

In 2013, the most important professional development needs reported by Swedish teachers are related to student evaluation and assessment practices, along with ICT skills for teaching and knowledge of the curriculum.

- Several state-supported education programmes have been initiated to enhance teachers' skills in specific areas (for example, Mathematics Boost and Counselling for Learning).

- In 2014-15, the government invested around 300m SEK in a pilot project aim to enhance teachers' professional development in the area of reading and writing. This is planned to continue full scale 2015-18.

Pedagogy, Curriculum and Classroom Culture. The 2015 OECD Sweden perspective notes attitudes of low expectations of students, high tolerance to disciplinary and truancy issues by schools and parents, and an apparent general feeling of complacency throughout large parts of the school system (Teacher Identities and Professionalism Research, 2019).

There is a strong focus on classroom-based assessments in Swedish schools, through which, teachers collect a range of evidence of students' progress and provide regular feedback. The NAE has many open courses in assessment and grading; however, the evidence suggests that teachers need to strengthen their formative and summative assessment skills. The Swedish Schools Inspectorate report finding teachers assessment skills underdeveloped, particularly in relation to implementing day-to-day formative assessment.

Collaboration and leadership. There is a long tradition of teamwork in Swedish schools, supported by a flat organisational structure. Teachers are typically organised into small groups which share responsibility for organising their work. Teachers also have a high degree of autonomy, and are required to contribute to school strategies to achieve the national student learning goals. 
Activities which bring teachers together to stimulate peer learning and increase cooperation include:

- Interpreting the curriculum and adapting to the locals context.

- Establishing student assessment methods.

- Ensuring fairness in the grading of national tests.

School development in Sweden involves as many staff as possible in the processes of self-evaluation, follow-up and improvement.

Teachers cite the benefits as:

- Support by colleagues.

- Shared responsibility for learning.

- Counselling of students - teamwork is perceived as essential to dealing with students in a comprehensive way.

In 2015, the NAE reported that many teachers do not have the conditions they need to be able to carry out good quality teaching, concluding that improvements to leadership were keys to addressing this. The NAE recommend that pedagogical leadership needs to occupy a greater portion of principal's day-to-day work, to give them the opportunity to monitor, analyse and take action in teacher development. This requires lightening principals' administrative burdens, and education providers taking greater responsibility for ensuring that principles have the right conditions to do a good job. Principals' challenging workload limits their ability to prioritise pedagogical leadership and causes stress and an unhealthy work-life balance (Teacher Identities and Professionalism Research, 2019). TALIS 2013 found that Swedish principals devote $51 \%$ of their time to administration.

Accountability and Assessment. Regular supervision of all municipal schools, from preschool to adult education -9 regional units undertake school visits throughout the country Providing qualitative feedback to schools, based on site visits and on-the-spot observations

The National Agency for Education (NAE) is responsible for National curriculum goals, managing the collection and analysis of quantative data, national follow-up and evaluation and developing support materials, such as advice and guidelines. The NAE are supported by the Swedish Schools Inspectorate who are responsible for: regular supervision of all municipal schools, from preschool to adult education -9 regional units undertake school visits throughout the country; providing qualitative feedback to schools, based on site visits and on-the-spot observations

Collaboration for better schools (2015) is a new initiative where the national agency is tasked with going into individual schools with great needs. They have the mandate together with the school to perform diagnosis and action planning. This is the first time a state-level agency has undertaken support and intervention in individual schools.

Conclusions and prospects for further research. Sweden is one of the leading countries in the field of education, in which the system of teacher training is gaining importance. Nowadays, Sweden has a distinctive system of teacher training and development, which has been significantly influenced by the European educational system. The Swedish national education system 
ensures the formation of a future teacher's professional readiness to implement the following components in their own activities: attitude towards people of different ages from a positive side; a benevolent attitude towards people from different social strata and material wealth; disclosure of the essence of the processes of integration and balancing of the economy, environment and society.

The system of professional education in Sweden operates in accordance with the following principles of the education quality: the availability of professional education for all citizens of Sweden, taking into account the needs and expectations of the individual for lifelong learning; mobility, which ensure the competitiveness of university graduates in the international educational space; scientific nature, which ensures the intellectual development of future teachers, etc. Sweden owns a high system of pedagogical education that, on the basis of national achievements and established world traditions, ensures the professional development of pedagogical personnel capable of carrying out professional activities on democratic and humanistic foundations, implementing educational policy as a priority function of the state aimed at the development and self-realization of the individual, satisfying his/her educational and spiritual-cultural needs.

Our overview of feathers of lifelong teacher education in Sweden does not put the issue to rest, as the experience of this country is unique and may require more in-depth analysis and systematization in further research. For example, the content of teacher training and teacher professional development as a part of adult education in Sweden.

\section{Biblioraphy}

Rabo, A. (2007). Teacher training in «multicultural» Sweden. EMIGRA Working Papers, 7. URL: https://core.ac.uk/download/pdf/13317845.pdf [in English].

Rabo, A. (2007). Reorganising teacher education in Sweden. Paradoxes of diversity in Education in 'Multicultural' Societies. Turkish and Swedish Perspectives, eds: Carlson, Marie, Annika Rabo, Fatma Gok. Swedish Research Institute in Istanbul, Transactions, 18 \& I. B. Tauris, London, 35-50 [in English].

Teacher Identities and Professionalism Research. (2019). Education International Study - Country Overview Poster. URL: https://download.eiie.org/Docs/WebDepot/Sweden\%20Poster.pdf [in English].

Sweden - Teaching Profession. (2020). URL: https://education.stateuniversity.com/pages/1466/Sweden-TEACHINGPROFESSION.html\#ixzz6zmQhMUeB [in English]. 